Sara Jerebic

ORCID: https://orcid.org/0000-0003-4597-2746

University of Ljubljana, Slovenia;

Family Institute Blizina, Slovenia

\title{
Sexual Abuse as Trauma and Posttraumatic Growth*
}

\section{Sexual abuse as trauma}

In the fifth edition of the DSM-5 (Diagnostic and Statistical Manual of Mental Disorders) $)^{1}$, sexual abuse is defined as trauma, whereby a traumatic event is defined as a direct or potential threat, which applies to the direct exposure to sexual violence, or witnessing another person's trauma, or being aware that a close person has been traumatized. DSM-5 enumerates various forms of sexual violence: forced sexual penetration, alcohol/ drug-facilitated sexual penetration, abusive sexual contact, noncontact sexual abuse, sexual trafficking ${ }^{2}$ and also child sexual abuse, which encompasses any sexual act involving a child that is intended to provide

* The authors acknowledge the partial financial support from the Slovenian Research Agency (project No. J5-9349).

1 American Psychiatric Association, Diagnostic and Statistical Manual of Mental Disorders, Fifth Edition, Arlington 2013: American Psychiatric Association.

2 American Psychiatric Association, Diagnostic and Statistical Manual of Mental Disorders, Fifth Edition, Arlington 2013: American Psychiatric Association, p. 274. 
sexual gratification to a parent, caregiver, or other individual in contact with the child. The latter also includes all forms of physical sexual contact and non-contact exploitations such as making a child participate in acts for the sexual gratification of others. ${ }^{3}$ However, since sexual abuse does not occur in isolation but always within a relationship, ${ }^{4}$ we speak of relational trauma, which is qualitatively and quantitatively more psychopathogenic than any other social or physical stress. ${ }^{5}$ Some authors define it as a complex psychological trauma characterized by exposure to strong causes of stress, which may be recurring or long-lasting, include harmful acts, and occur at a developmentally sensitive time, such as early childhood or adolescence, which are critical periods of brain development. ${ }^{6}$ Hereinafter, we shall present the neurobiology of trauma, through understanding the brain, and we shall try to answer the question why some survivors of sexual abuse are overwhelmed with extreme emotional responses and strong physical sensations when memories of past experiences are triggered, hampering their functioning in family relationships.

\subsection{Sexual abuse trauma and memory}

To understand how abuse-related trauma is connected with memory, we shall first have a look at the neurobiology of trauma.

Scientific research ${ }^{7}$ shows how trauma affects the hippocampus and amygdala that are located in the limbic part of the brain. The hippocampus processes the information necessary for the meaning of experiences in time and place, while the amygdala processes and accelerates the storage of emotions and reactions in emotionally charged situations. ${ }^{8}$ The amygdala is

3 American Psychiatric Association, Diagnostic and Statistical Manual of Mental Disorders, Fifth Edition, Arlington 2013: American Psychiatric Association, p. 718.

$4 \quad$ J. L. Herman, Trauma and recovery, London 1997, Pandora.

5 A. N. Schore, Affect regulation and the Repair of the Self, New York 2003, W W Norton \& Co.

6 C. A. Courtois, J. D. Ford, Treating complex traumatic stress disorders: an evidencebased guide, New York 2009, London: Guilford.

7 J. D. Bremner, P. Randall, E. Vermetten, L. Staib, R. A. Bronen, C. Mazure, S. Capelli, G. McCarthy, R. B. Innis, D. S. Charney, Magnetic resonance imaging-based measurement of hippocampal volume in posttraumatic stress disorder related to childhood physical and sexual abuse--a preliminary report, "Biological Psychiatry" 41 (1997) 1, pp. 23-32.

8 B. Rothschild, The body remembers: the psychophysiology of trauma and trauma treatment, New York 2000, Norton. 
related to emotional learning as a response to certain situations perceived as dangerous. ${ }^{9}$ Both the hippocampus and the amygdala are strongly affected by the experience of chronic stress and trauma. The more stress increases, the higher amount of stressful hormones and neurochemicals are secreted, stifling the hippocampus. ${ }^{10}$ Research shows that the volume of the hippocampus in sexually abused children is smaller in comparison to those who were not abused. ${ }^{11}$ The neurotransmitter noradrenaline, secreted when the sympathetic nervous system is activated during a stressful or upsetting event, is thus released into the amygdala and strengthens a traumatic memory. ${ }^{12}$ The autonomic nervous system is, therefore, constantly under severe stress, in a state of constant alertness, and a feeling of being overwhelmed, destroying the ability to integrate what has happened. Sensations, affects, and thinking are dispersed into sensory fragments and are disconnected. This means that trauma is stuck in the amygdala and chronic arousal in the autonomic nervous system can lead to posttraumatic stress disorder (PTSD), ${ }^{13}$ which is the best known expression of the consequences of unprocessed traumatic or severely stressful events. ${ }^{14}$

\subsection{Post-traumatic stress disorder}

Post-traumatic stress disorder (PTSD) is a mental disorder that affects an individual's life in various ways. It is defined by four groups of symptoms:

9 B. A. Van der Kolk, Beyond the talking cure: somatic experience and subcortical imprints in the treatment of trauma, in: F. Shapiro (eds.), EMDR as an integrative psychotherapy approach: experts of diverse orientations explore the paradigm prism, Washington 2002, American Psychological Association.

10 L. Cahill, L. Gorski, K. Le, Enhanced human memory consolidation with post-learning stress: interaction with the degree of arousal at encoding, "Learning \& Memory" 10 (2003) 4, pp. 270-274.

11 J. D. Bremner, P. Randall, E. Vermetten, L. Staib, R. A. Bronen, C. Mazure, S. Capelli, G. McCarthy, R. B. Innis, D. S. Charney, Magnetic resonance imaging-based measurement of hippocampal volume in posttraumatic stress disorder related to childhood physical and sexual abuse--a preliminary report, "Biological Psychiatry" 41 (1997) 1, pp. 23-32.

12 L. Cahill, L. Gorski, K. Le, Enhanced human memory consolidation with post-learning stress: interaction with the degree of arousal at encoding, "Learning \& Memory" 10 (2003) 4, pp. 270-274.

13 B. Rothschild, The body remembers: the psychophysiology of trauma and trauma treatment, New York 2000, Norton.

14 R. Cvetek, Bolečina preteklosti: travma, medosebni odnosi, družina, terapija, Celje 2009, Celjska Mohorjeva družba. 
intrusion, avoidance, negative alternations in cognitions and mood, and alterations in arousal and reactivity. ${ }^{15}$

\subsubsection{Intrusion symptoms}

Reliving some aspects of unprocessed traumatic events takes place at the mental, emotional, behavioural or physical level. It may involve intrusive thoughts, images, feelings, nightmares, severe mental distress or serious concern. ${ }^{16}$ At the body level, it can lead to the development of somatization, such as headaches and various pains, or even gastroenterological diseases. ${ }^{17}$ Intrusive thoughts may manifest as flashbacks, which are related to dissociation, and prevent the individual from distinguishing what originates in the past and what comes from the present. They can be triggered by the senses of smell, taste, touch, sight and sound. ${ }^{18}$ If we draw a parallel with family relationships, flashbacks can be triggered by partner's initiative in sexuality or the feelings of helplessness with a newborn who needs to be taken care of. In behavioural reliving, behavioural responses can be similar to those at the time of abuse; for example, if a little girl was sexually abused by an uncle when he was supposed to look after her, and he was chasing her around the house while she tried to flee from him, her frequent response as an adult might be the flight from danger or fight as self-defence. This can turn out to be a problem in intimate couple relationships, when the wife can be overly responsive to every husband's minor threat, which is not even a threat, but is perceived by her as such due to past trauma, so that she reacts with excessive arousal and aggression. Because of sleep problems and excessive responsiveness, survivors of childhood sexual abuse can be extremely irritable, which can manifest in intense outbreaks of rage ${ }^{19}$ and increased impulsivity that harmfully affect their intimate life. ${ }^{20}$

\footnotetext{
15 American Psychiatric Association, Diagnostic and Statistical Manual of Mental Disorders, Fifth Edition, Arlington 2013: American Psychiatric Association, pp. 271-276.

16 E. B. Carlson, Trauma assessments: A clinician's guide, New York 1997, Guilford Press.

17 E. B. Carlson, Trauma assessments: A clinician's guide, New York 1997, Guilford Press.

18 B. Rothschild, The body remembers: the psychophysiology of trauma and trauma treatment, New York 2000, Norton.

19 B. A. Van der Kolk, The psychobiology and psychopharmacology of PTSD, "Human psychopharmacology: clinical and experimental“ 16 (2001) 1, pp. 49-64.

20 B. Mills, G. Turnbull, Broken hearts and mending bodies: the impact of trauma on intimacy, "Sexual and Relationship Therapy" 19 (2004) 3, pp. 265-289.
} 


\subsubsection{Avoidance}

Strenuous reliving can lead to various avoidance symptoms on mental, emotional, behavioural or physical levels manifested as isolation and loneliness, when the individual avoids people and generally everything that could remind her of the trauma of abuse. Symptoms include emotional bluntness, drug and/or alcohol abuse, which can lead to addiction, and highrisk behaviours. ${ }^{21}$ On the body level, they dull the pain, and by means of the symptoms mentioned above, she tries to protect herself from anxiety and sensations related to past trauma. ${ }^{22}$ Avoidance includes significantly reduced interest or participation in important activities, and a sense of separation and alienation from others, which hinders interpersonal intimacy. ${ }^{23}$

\subsubsection{Negative alternations in cognitions and mood}

One of the most difficult symptoms of PTSD is a negatively altered mood. Some persons may lose interest in things that they want to enjoy, be unable to concentrate, they experience feelings of alienation from others, and are constantly incapable of experiencing positive emotions. They are also incapable of remembering the important aspects of trauma, have negative beliefs about themselves or the world, distorted cognition about cause and effect, they blame themselves for abuse. In this persistent emotional state they experience horror, fear, anger, guilt or shame. ${ }^{24}$

\subsubsection{Alterations in arousal and reactivity}

Hyperarousal or increased arousal manifests with persistent symptoms such as sleep disorders, when a person finds it difficult to fall asleep or awakens at night, has problems with concentration, and behaves recklessly and selfdestructively. ${ }^{25}$ Because of sleep problems and excessive responses, the sexually abused are highly irritable, possibly escalating in outbreaks of rage. ${ }^{26}$

\footnotetext{
21 B. Girardin, Color atlas of sexual assault, St. Louis, London 1997, Mosby.

22 Carlson E. B., Trauma assessments: A clinician's guide, New York 1997: Guilford Press.

23 B. Mills, G. Turnbull, Broken hearts and mending bodies: the impact of trauma on intimacy, "Sexual and Relationship Therapy" 19 (2004) 3, pp. 265-289.

24 American Psychiatric Association, Diagnostic and Statistical Manual of Mental Disorders, Fifth Edition, Arlington 2013: American Psychiatric Association, p. 272.

25 R. Cvetek, Bolečina preteklosti: travma, medosebni odnosi, družina, terapija, Celje 2009, Celjska Mohorjeva družba.

26 B. A. Van der Kolk, The psychobiology and psychopharmacology of PTSD, "Human psychopharmacology: clinical and experimental“ 16 (2001) 1, pp. 49-64.
} 


\subsubsection{Dissociation}

Dissociation is the way in which sexually abused individuals protect themselves from strong emotions caused by repetitive trauma, e.g. anger, rage, fear and despair. When these difficult affects are too overwhelming, the defence of dissociation is turned on automatically. ${ }^{27}$ Prominent dissociative symptoms can be depersonalization (feeling detached from one's own mind and/or body) or derealization (experiencing the world as unreal, dreamlike or having distorted perceptions). ${ }^{28}$ Children, as well as adults, describe how in stressful situations they can simply 'disappear' and observe from a distance what is happening around them. They feel as if what is happening is not happening to them but to someone else. ${ }^{29}$ They can say to themselves, "This is not happening to me," and watch the abuse from a distance. Although dissociation may be a resourceful defence mechanism during the trauma of abuse, it is pathological when it becomes the primary response to stress, namely, when stressful situations occur that can make communication and solving problems between family members more difficult. Many of the mentioned trauma symptoms refer to problems experienced by the individual as reactions to the traumatic event, and several have more interpersonal effects.

\section{Systemic dimensions of trauma}

Traumatic stress research shows that those who are in direct contact with individuals who have experienced childhood sexual abuse trauma also experience symptoms of trauma on their own, which is especially true for the partners of sexual abuse survivors. ${ }^{30}$

\footnotetext{
27 P. Stien, J. Kendall, Psychological trauma and the developing brain, New York 2004, Haworth.

28 American Psychiatric Association, Diagnostic and Statistical Manual of Mental Disorders, Fifth Edition, Arlington 2013: American Psychiatric Association, p. 274.

29 B. A. Van Der Kolk, J. A. Burbridge, J. Suzuki, The psychobiology of traumatic memory. Clinical implications of neuroimaging studies, in: R. Yehuda, A. C. McFarlane (eds.), Annals Of The New York Academy Of Sciences, New York 1997, pp. 99-113.

30 C. R. Figley, H. I. McCubbin, Stress and the family, New York 1983, Brunner/Mazel.
} 
In the following sections we shall present secondary traumatization, which describes the consequences for individuals who are in direct contact with the person who was traumatized. ${ }^{31}$

\subsection{Secondary traumatization}

In literature, secondary traumatization is most frequently described with the following expressions: ${ }^{32}$

- Secondary traumatic stress

- Compassion fatigue

- Vicarious traumatization

- Burnout.

Secondary traumatic stress involves various ways of trauma transmission, which means that the traumatic experience of sexual abuse can be extended from one family member to the whole family, affecting its functionality, regardless of when trauma has occurred. ${ }^{33}$ The symptoms are almost identical to the symptoms of PTSD, but they differ as far as their intensity and regulation are concerned. ${ }^{34}$

Clinical literature shows that close relatives of a traumatized person can themselves experience secondary effects of trauma, which can lead to interpersonal distress. ${ }^{35}$ Partners often report symptoms such as the feelings of anger, sadness, shame and fear. ${ }^{36}$

Thus, not only the person who was sexually abused but also all persons who are close in contact with her, especially her partner, suffer from

31 C. Maltas, P. Carolynn, J. Shay, Trauma contagion in partners of survivors of childhood sexual abuse, "American Journal of Orthopsychiatry" 65 (1995) 4, pp. 529-539.

32 C. R. Figley, Compassion fatigue: coping with secondary traumatic stress disorder in those who treat the traumatized, New York 1995, Brunner/Mazel.

33 J. Lebow, K. Newcomb Rekart, Research assessing couple and family therapies for posttraumatic stress disorder, in: D. R. Catherall (eds.), Handbook of stress, trauma and the family, New York 2004, Routledge.

34 C. R. Figley, Compassion fatigue: coping with secondary traumatic stress disorder in those who treat the traumatized, New York 1995, Brunner/Mazel.

${ }^{35}$ B. S. Nelson, K. S. Wampler, Systemic effects of trauma in clinic couples: an exploratory study of secondary trauma resulting from childhood abuse, "Journal of Marital \& Family Therapy" 26 (2000) 2, pp. 171-184.

${ }_{36}$ S. M. Johnson, L. Williams-Keeler, Creating healing relationships for couples dealing with trauma: the use of emotionally focused marital therapy, "Journal of Marital and Family Therapy” 24 (1998) 1, pp. 25-40. 
trauma. Literature has observed the differences, however, between singletrauma couples and dual-trauma couples, that is when both partners have experienced trauma.

\subsubsection{Trauma in a couple}

Single-trauma couples are those in which only one of both partners has had a traumatic experience, where traumatic symptoms of stress are transmitted to the other partner and their effects are similar to those in PTSD, only somehow weaker. In dual-trauma couples, on the other hand, both partners have experienced one or more traumatic events, which affects them as individuals, as well as their functioning in their interpersonal relationship. ${ }^{37}$ Their trauma contributes to their relationship issues.

On the basis of clinical practice by Nelson and colleagues, various interpersonal dynamics of traumatized couples were identified: ${ }^{38}$

In single-trauma couples:

- The polarization of emotional roles:

One of the spouses/partners expresses emotions strongly, while the other controls them, which is reflected in interpersonal communication.

- The pursue-withdraw pattern:

One of the spouses/partners pushes or pursues, the other withdraws, which is strongly manifested in conflict situations when one of them wants to exercise control over the other.

- The role of secrecy:

The traumatized partner does not reveal her trauma to the other, and if she does, she only mentions it, but does not discuss details. On the other hand, the partner who has not experienced trauma avoids conversation about this topic for various reasons (fear, shame, denial, or minimization).

- The individual problems of the traumatized partner:

These include PTSD, low self-esteem, poor self-care; they affect the individual's behaviour and need to be addressed within a couple.

37 D. Balcom, The interpersonal dynamics and treatment of dual trauma couples, "Journal of Marital and Family Therapy" 22 (1996) 4, pp. 431-442.

38 B. S. Nelson, S. Wangsgaard, J. Yorgason, M. Higgins Kessler, E. Carter-Vassol, Singleand dual-trauma couples: clinical observations of relational characteristics and dynamics, "American Journal of Orthopsychiatry" 72 (2002) 1, pp. 58. 
- The individual problems of the non-traumatized partner:

It is an inability to understand the traumatized partner and the lack of empathy. The non-traumatized partner can even blame the traumatized partner for the problems that have arisen or is angry with her.

- The parental role of the non-traumatized partner:

When the traumatized partner, due to individual symptoms of trauma, is incapable or only partly capable of taking care of herself, this dynamics requires from the non-traumatized partner to take on the major role in the functioning of the whole family, or a role of a parent (parenting the partner).

- Impact on other systems:

Problems in intimate couple relationship affect children subsystem so that the children become parentified or, because they subconsciously try to establish the equilibrium of the family system, develop problematic behaviours.

In dual-trauma couples:

- Power and control issues:

They occur when one of the partners/spouses takes control of important aspects in a relationship, such as sexuality, finances, emotions, leisure time, etc., while the other partner has limited control in there areas.

- Competitiveness between spouses/partners: They may compete as to whose trauma is more severe, or develop the tendency towards the role of a victim who requires additional care.

- The ambiguity of external boundaries:

Their boundaries related to the entering of the third person are either very open or very much closed.

- Trauma-related symptoms: They have problems in sexuality.

- Overwhelmed-rejecting couples:

Many couples take on complementary roles within their relationship as the response to traumatic experiences. One of the partners becomes overwhelmed by the effects of the traumatic experiences, while the other rejects or denies them. The overwhelmed partner thus takes on both traumas, because in this way he or she rescues the other and takes care of reducing the emotional tension in the relationship. 
- Current behaviour and past experiences:

One or both partners/spouses may minimalize the impact of past experiences on their current behaviour.

- Guilt:

Guilt can originate from sexual abuse.

The trauma of sexual abuse in childhood thus affects the neurobiology of the abused, which is reflected on the cognitive, emotional and behavioural levels, and finds its most intense expression in interpersonal couple relationships. The presented effects offer a clear insight into the distress experienced by survivors, but as we believe in Christianity, there is no resurrection without a cross: despite the painful experience with many consequences we can see growth, which is defined in the literature as posttraumatic growth (PTG).

\section{Post-traumatic growth}

Post-traumatic growth is understood as an experience of positive psychological changes that result from the struggle with life circumstances and pose a great challenge; ${ }^{39}$ sexual abuse trauma is one of these circumstances. Tedeschi and Calhoun ${ }^{40}$ were the first to define posttraumatic growth (PTG), identifying its five dimensions as follows:

- Increased respect of life

- Setting priorities in life (change in the hierarchy of importance)

- Warmer and more emotionally intimate relationships with others

- A stronger feeling of one's personal power

- Recognizing new possibilities in life

- Spiritual evolvement.

This is a "significant beneficial change in cognitive and emotional life beyond previous levels of adaptation, psychological function, or life awareness." ${ }^{\text {11 }}$ Some individuals who are exposed to traumatic events can

39 R. G. Tedeschi, L.G. Calhoun, Posttraumatic growth: conceptual foundations and empirical evidence, "Psychological inquiry" 15 (2004) 1, pp. 1-18.

$40 \quad$ R. G. Tedeschi, L.G. Calhoun, Posttraumatic growth: conceptual foundations and empirical evidence, "Psychological inquiry" 15 (2004) 1, pp. 1-18.

41 R. G. Tedeschi, L.G. Calhoun, Posttraumatic growth: conceptual foundations and empirical evidence, "Psychological inquiry" 15 (2004) 1, pp. 1-18. 
experience emotional growth and develop stronger trust in their ability to cope with difficult situations. If they felt completely helpless during sexual abuse, when facing the consequences in crises and difficulties, they discover inner power they have never known before. Others recognize the importance of relationships that were previously taken for granted, and they can improve and deepen their connection with family members and friends. ${ }^{42}$ After struggling with severe stress, individuals can become more emotionally expressive; they are ready for a higher level of emotional selfdisclosure, they are more open to receiving help and support from others, and some begin to feel more appreciation for life. If the abused previously questioned where God was when they were being abused, later through suffering, they can develop a genuine relationship with God, i.e. they personally experience God. ${ }^{43}$

\subsection{Research on post-traumatic growth after sexual violence}

Research has confirmed post-traumatic growth in people who have experienced sexual abuse, but it has not yet been established how and when post-traumatic growth occurs. Researchers ${ }^{44}$ reviewed 54 articles and dissertations on PTG and sexual victimization and 17 included in an exploratory study. They found that prior to 1980 there were no articles on the topic of post-traumatic growth in the survivors of childhood sexual abuse, and they found that authors used different terms for positive changes in the life of an individual: post-traumatic growth is described as growth, positive adjustment, positive life changes and positive sequels, based on the victim's perception of change. All research has shown that between $25 \%$ and $67 \%$ of participants experienced some form of growth. ${ }^{45}$ The authors have found that from study to study, the nature of PTG varies among the victims

\footnotetext{
42 L.G. Calhoun, R.G. Tedeschi, Posttraumatic Growth in Clinical Practice. New York 2013: Routledge.

43 L.G. Calhoun, R.G. Tedeschi, Posttraumatic Growth in Clinical Practice. New York 2013: Routledge.

44 E. Ulloa, M.L. Guzman, M. Salazar \& C. Cala, Posttraumatic Growth and Sexual Violence: A Literature Review, "Journal of Aggression, Maltreatment \& Trauma" 25 (2016) Nr. 3, pp 286-304.

45 E. Ulloa, M.L. Guzman, M. Salazar \& C. Cala, Posttraumatic Growth and Sexual Violence: A Literature Review, "Journal of Aggression, Maltreatment \& Trauma" 25 (2016) Nr. 3, pp. 293.
} 
of sexual assault. Some participants began to value life, others relationships with others, and especially the support of family and friends. They reported improved relationships with their mothers, increased empathy towards others and spiritual growth, and above all personal strength and a stronger sense of self. They saw new opportunities as a form of growth. Some have become socially and politically active after their traumatic experiences, and they advocate the rights of sexually abused and the reporting of sexual violence. ${ }^{46}$ Due to methodological differences, it was difficult to determine when exactly the PTG occurred in the participants, but empathy was a recurring theme throughout all articles. Research also showed the importance of the identity of the perpetrator, where sexual violence differs from other forms of trauma. In revealing re-victimization, which occurs when the perpetrators are family members or the husband, it has been found that that growth can be severely hindered. ${ }^{47}$ This is understandable; if victims lived in an environment where they were not safe, their trust and the feeling of safety were low, and at the same time they could not turn for help to their close person, if this person was the perpetrator. Control proved to be an important element in the study. Those who have experienced more control over their recovery, report more positive changes in life because it fosters a successful coping process. However, two extremes have been identified in the connection of PTG and distress symptomology. In some studies, the authors reported positive correlation. Higher PTG levels were associated with greater PTSD and depression, while some reported the opposite. Some authors of this research believe that the correlation may also depend on other factors, such as personality traits or attachment styles. Post-traumatic growth is, therefore, also associated with safe attachment, which applies in a therapeutic relationship, too. ${ }^{48}$ Many individuals and couples who have experienced sexual abuse find psychotherapeutic help. The therapist can contribute to further growth with their attitude.

\footnotetext{
$46 \quad$ E. Ulloa, M.L. Guzman, M. Salazar \& C. Cala, Posttraumatic Growth and Sexual Violence: A Literature Review, "Journal of Aggression, Maltreatment \& Trauma" 25 (2016) Nr. 3, pp. 295.

47 E. Ulloa, M.L. Guzman, M. Salazar \& C. Cala, Posttraumatic Growth and Sexual Violence: A Literature Review, "Journal of Aggression, Maltreatment \& Trauma" 25 (2016) Nr. 3, pp. 296.

48 R. G. Tedeschi, L.G. Calhoun, Posttraumatic growth: conceptual foundations and empirical evidence, "Psychological inquiry" 15 (2004) 1, pp. 1-18.
} 


\section{The support of a therapeutic relationship in post-traumatic growth}

Therapeutic treatment is central to therapy, especially for clients who have experienced sexual abuse trauma. Because their trust was violated, they are hardly, if at all, able to trust, and therefore, need an understanding and compassionate therapist. In the study, ${ }^{49}$ the aim of which was to provide both a theoretical and practical overview of post-traumatic growth in therapy from the point of view of relational family therapists with severalyear therapeutic experience in working with trauma, mostly with sexually abused clients, it was found that the agent of change was emotional processing. Clients mostly process shame and guilt; not so much the shame and guilt related to abuse itself, but rather to the effects of their behaviour, something painful they feel they continue to do to themselves. A safe therapeutic atmosphere, where self-disclosure is encouraged, accompanied by compassion, makes it possible for the client to move towards growth. It was found that a genuine and spontaneous affective meeting between the therapist and the client is crucial. Empathy reduces clients' loneliness and makes them feel connected. According to the author, empirical research shows that PTG is inextricably connected with love, compassion, honesty, and commitment to the mission of therapists' work. The central point of relational family paradigm is human longing for the sacred, the transcendental, which means that an essential, fundamental human need is to be connected with another, ${ }^{50}$ to feel unconditionally loved and accepted. An individual who does not have this experience, will therefore feel unworthy, not good enough, inadequate, and finally discarded, and she will try to protect herself against these disruptive feelings with a variety of means, among which addiction is quite frequent. Thus, a relationship with God can provide the safe space where she will experience the unconditional, where she will feel worthy, adequate and loved, and will consequently be able to change the attitude towards herself and others, to change her selfperception, and gradually deal with painful feelings from which she used to

49 M. Adamič, Proces potravmatske rasti v relacijski družinski terapiji: magistrsko delo, Univerza v Ljubljani, Teološka fakulteta 2016, M. Adamič.

50 C. Gostečnik, Psihoanaliza in religiozno izkustvo: [religiozno izkustvo, sakralni prostor, relacijska družinska teorija, sakralni odnos, hrepenenje po drugem, iskanje drugega in Boga], Ljubljana 2005, Brat Frančišek. 
flee so persistently. In the language of relational family therapy, this means that only after establishing a profound relationship with God, with someone she feels loved by, accepted and worthy, will she be able to abandon the painful affective psychic constructs she used to regulate painful affects. When the individual thus begins to perceive herself in a new way, when she establishes a new attitude towards herself, when she ceases to feel lonely, when this basic pain of being discarded is resolved, then the compulsive attachment to the repetition of the same complications and, consequently, to addiction is released and the space opens up for something entirely new. In the relational family paradigm, this novelty is new affect regulation, a new way of self-perception, and a new way of establishing family relationship $s^{51}$ which is, in the case of sexual abuse trauma, post-traumatic growth.

\section{Bibliography}

Adamič M., Proces potravmatske rasti v relacijski družinski terapiji: magistrsko delo, Univerza v Ljubljani, Teološka fakulteta 2016: M. Adamič.

American Psychiatric Association, Diagnostic and Statistical Manual of Mental Disorders, Fifth Edition, Arlington 2013: American Psychiatric Association.

Balcom D., The interpersonal dynamics and treatment of dual trauma couples, "Journal of Marital and Family Therapy" 22 (1996) Nr. 4, pp. 431-442.

Bremner J. D., Randall P., Vermetten E., Staib L., Bronen R. A., Mazure C., Capelli S., McCarthy G., Innis R. B., Charney D. S., Magnetic resonance imaging-based measurement of hippocampal volume in posttraumatic stress disorder related to childhood physical and sexual abuse--a preliminary report, "Biological Psychiatry" 41 (1997) Nr. 1, pp. 23-32.

\footnotetext{
51 D. Jerebic, S. Jerebic, Različni modeli zdravljenja odvisnosti in relacijska družinska terapija, "Bogoslovni vestnik" 72 (2012) 2, pp. 297-309; J. Stala, Geistig behinderte Kinder religiös erziehen - Herausforderungen an Pädagogik und Katechese, „The Person and the Challenges" 4 (2014) nr 2, pp. 221-234; J. Stala, Der gesellschaftlich-kulturelle Kontext der aktuellen Gefährdungen für die religiöse Erziehung und Bildung in der Familie, „The Person and the Challenges" 3 (2013) nr 1, pp. 251-266; J. Stala, Der Mensch als Person: Die bestimmende Grundlage für Johannes Paul II. in seinem Bild von der Familie, „The Person and the Challenges" 2 (2012) nr 2, pp. 41-59.
} 
Cahill L., Gorski L., Le K., Enhanced human memory consolidation with post-learning stress: interaction with the degree of arousal at encoding, "Learning \& Memory" 10 (2003), Nr. 4, pp. 270-274.

Calhoun L.G., Tedeschi G. R., Posttraumatic Growth in Clinical Practice. New York 2013: Routledge.

Carlson E. B., Trauma assessments: A clinician's guide, New York 1997: Guilford Press.

Courtois C. A., Ford J. D., Treating complex traumatic stress disorders: an evidence-based guide, New York 2009: London: Guilford.

Cvetek R., Bolečina preteklosti: travma, medosebni odnosi, družina, terapija, Celje 2009: Celjska Mohorjeva družba.

Figley C. R., Compassion fatigue: coping with secondary traumatic stress disorder in those who treat the traumatized, New York 1995: Brunner/ Mazel.

Figley C. R., McCubbin H. I., Stress and the family, New York 1983: Brunner/ Mazel.

Girardin B., Color atlas of sexual assault, St. Louis, London 1997: Mosby.

Gostečnik C., Psihoanaliza in religiozno izkustvo: [religiozno izkustvo, sakralni prostor, relacijska družinska teorija, sakralni odnos, hrepenenje po drugem, iskanje drugega in Boga], Ljubljana 2005: Brat Frančišek.

Herman J. L., Trauma and recovery, London 1997: Pandora.

Jerebic D., Jerebic S., Različni modeli zdravljenja odvisnosti in relacijska družinska terapija, "Bogoslovni vestnik" 72 (2012) Nr. 2, pp. 297-309.

Johnson S. M., Williams Keeler L., Creating healing relationships for couples dealing with trauma: the use of emotionally focused marital therapy, "Journal of Marital and Family Therapy" 24 (1998) Nr. 1, pp. 25-40.

Lebow J. Newcomb Rekart K., Research assessing couple and family therapies for posttraumatic stress disorder, in: D. R. Catherall (eds.), Handbook of stress, trauma and the family, New York 2004: Routledge.

Maltas C., Carolynn P., Shay J., Trauma contagion in partners of survivors of childhood sexual abuse, "American Journal of Orthopsychiatry" 65 (1995) Nr. 4, pp. 529-539.

Mills B., Turnbull G., Broken hearts and mending bodies: the impact of trauma on intimacy, "Sexual and Relationship Therapy" 19 (2004) Nr. 3, pp. 265-289. 
Nelson B. S., Wampler K. S., Systemic effects of trauma in clinic couples: an exploratory study of secondary trauma resulting from childhood abuse, "Journal of Marital \& Family Therapy" 26 (2000) Nr. 2, pp. 171-184.

Nelson B. S., Wangsgaard S., Yorgason J., Higgins Kessler M., Carter-Vassol E., Single-and dual-trauma couples: clinical observations of relational characteristics and dynamics, "American Journal of Orthopsychiatry" 72 (2002) Nr. 1, pp. 58.

Rothschild B., The body remembers: the psychophysiology of trauma and trauma treatment, New York 2000: Norton.

Schore A. N., Affect regulation and the repair of the self (Norton series on interpersonal neurobiology), New York 2003: WW Norton \& Company.

Stala J., Geistig behinderte Kinder religiös erziehen - Herausforderungen an Pädagogik und Katechese, „The Person and the Challenges” 4 (2014) nr 2, pp. 221-234.

Stala J., Der gesellschaftlich-kulturelle Kontext der aktuellen Gefährdungen für die religiöse Erziehung und Bildung in der Familie, "The Person and the Challenges" 3 (2013) nr 1, pp. 251-266.

Stala J., Der Mensch als Person: Die bestimmende Grundlage für Johannes Paul II. in seinem Bild von der Familie, „The Person and the Challenges” 2 (2012) nr 2, pp. 41-59.

Stien P., Kendall J., Psychological trauma and the developing brain, New York 2004: Haworth.

Tedeschi R. G., Calhoun L. G., Posttraumatic growth: conceptual foundations and empirical evidence, "Psychological inquiry" 15 (2004) Nr. 1, pp. 1-18.

Tedeschi R. G., Lawrence G. C., The Postraumatic Growth Inventory: Measuring the Positive Legacy of Trauma, "Journal of Traumatic Stress" 9 (1996) Nr. 3, pp. 455-471.

Ulloa, E., Guzman, M. L., Salazar, M., \& Cala, C., Posttraumatic Growth and Sexual Violence: A Literature Review, "Journal of Aggression, Maltreatment \& Trauma”, 25 (2016) Nr. 3, pp 286-304.

Van der Kolk B. A., Burbridge J. A., Suzuki J., The psychobiology of traumatic memory. Clinical implications of neuroimaging studies, in: R. Yehuda, A. C. McFarlane (eds.), "Annals of the New York Academy of Sciences" 8 (1997), Nr. 21, pp. 99-113. 
Van der Kolk B. A., The psychobiology and psychopharmacology of PTSD, "Human psychopharmacology: clinical and experimental" 16 (2001) Nr. 1, pp. 49-64.

Van der Kolk B. A., Beyond the talking cure: somatic experience and subcortical imprints in the treatment of trauma, in: F. Shapiro (eds.), EMDR as an integrative psychotherapy approach: experts of diverse orientations explore the paradigm prism, Washington 2002: American Psychological Association. 
